\title{
Satisfaction of Low Carbon Society \\ - Latest Technical Approach on Coal-Fired Power Plant*
}

\author{
Yukiya MURANO** \\ **Energy Systems Operations, IHI Corporation \\ Toyosu IHI Building 1-1, Toyosu 3-chome, Koto-ku, Tokyo 135-8710, Japan \\ E-mail: yukiya_murano@ihi.co.jp
}

\begin{abstract}
IHI Corporation (IHI), as a supplier of power plant equipment including boiler, is facing to $\mathrm{CO}_{2}$ emission issue by various technical approaches. Latest status of advanced technologies, which is Advanced Ultra Super Critical Boiler (A-USC) Improvement in Efficiency, Oxy-fuel Combustion Technology $-\mathrm{CO}_{2}$ Capture and Use of Biomass Fuel - Renewable Energy, is introduced in this paper. Finally, these advanced technologies certainly contribute to reduce $\mathrm{CO}_{2}$ emission economically.
\end{abstract}

Key words: Thermal Power Generation, Boiler, $\mathrm{CO}_{2}$ Emission, Advanced Ultra Super Critical Boiler, Oxy-Fuel Combustion, Renewable Energy

\section{Introduction}

The global warming is one of the big issues for preservation of global environment. So, the use of nuclear energy and/or nature energy, as energy source not to generate $\mathrm{CO}_{2}$, will increase. However, the coal-fired power plant will be still major electricity source in the future from the viewpoint of economical reasons, stability of electricity and fuel security reasons. Therefore, the reducing $\mathrm{CO}_{2}$ from coal-fired power plant is urgently required. IHI is facing the $\mathrm{CO}_{2}$ emission issue by various technical approaches. In the viewpoint of Thermal Power Plant technology, there are three major approaches to reduce $\mathrm{CO}_{2}$ emission from coal-fired power plant.

The first approach is to improve the efficiency to convert fuel to electricity. This will be directly reducing the use of fuel and $\mathrm{CO}_{2}$ emission. The second approach is to capture $\mathrm{CO}_{2}$ from thermal power plants. Several methods are suggested in the system to capture $\mathrm{CO}_{2}$ from thermal power plant. An advanced $\mathrm{CO}_{2}$ capture system with oxy-fuel combustion technology has been developed. And the third approach is to use biomass fuel as renewable energy (carbon neutral resource).

Latest status of advanced coal-fired boiler technologies for global warming prevention is introduced.

\section{Advanced Ultra Super Critical Boiler (A-USC)}

\subsection{Achievement of USC Boilers ${ }^{(1)(2)(3)}$}

The USC boiler, whose steam temperature is over 593deg-C, is the state-of-the-art technology for power generation in a cost effective and environmentally acceptable manner. As shown in Fig.2.1, it has high net plant efficiency, with significantly lower fuel consumption and emissions when compared with conventional power plants.

In Japan, where a significant amount of the energy fuel resource on imported coal, the 
1993. USC-PC technology is based on long term operating experiences including sub-critical and super-critical conventional power plants.

Table 2.1 shows USC-PC boilers supplied or under construction by IHI. These boilers meet strict requirement for effective performance and environmental protection and have achieved high reliability since 1993 .

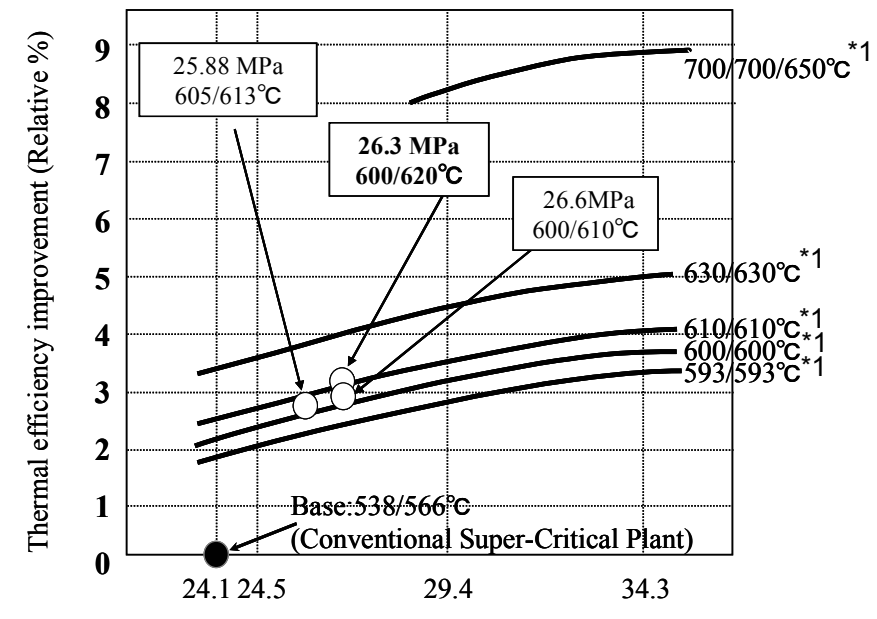

Main steam pressure (MPa)

*1 ( Main steam temp. / Reheat steam temp. ${ }^{\circ} \mathrm{C}$ )

Fig. 2.1 Thermal Efficiency Improvement by Applying USC Steam Conditions

Table 2.1 USC boiler experience supplied by IHI since 1993

\begin{tabular}{|l|c|c|c|c|}
\hline Plant Name & $\begin{array}{c}\text { Output } \\
(\mathrm{MW})\end{array}$ & $\begin{array}{c}\text { Capacity } \\
(\mathrm{t} / \mathrm{h})\end{array}$ & $\begin{array}{c}\text { Steam Condition } * 1 \\
\left(\mathrm{MPa} /{ }^{\circ} \mathrm{C} /{ }^{\circ} \mathrm{C}\right)\end{array}$ & $\begin{array}{c}\text { COD*3 } \\
\text { (year })\end{array}$ \\
\hline Hekinan No.3 & 700 & 2,250 & $25.0 / 543 / 596$ & 1993 \\
\hline Noshiro No.2 & 600 & 1,860 & $25.0 / 570 / 596$ & 1994 \\
\hline Nanao Ohta No.2 & 700 & 2,120 & $25.0 / 597 / 595$ & 1998 \\
\hline Tachibanawan No.1 & 1,050 & 3,000 & $25.9 / 605 / 613$ & 2000 \\
\hline Hekinan No.4 & 1,000 & 3,050 & $25.0 / 571 / 596$ & 2001 \\
\hline Hekinan No.5 & 1,000 & 3,050 & $25.0 / 571 / 596$ & 2002 \\
\hline Tomato Atsuma No.4 & 700 & 2,040 & $25.9 / 603 / 602$ & 2002 \\
\hline Isogo New No.1 *2 & 600 & 1,710 & $27.5 / 605 / 613$ & 2002 \\
\hline Isogo New No.2 $* 2$ & 600 & 1,670 & $27.2 / 605 / 623$ & 2009 \\
\hline Maizuru No.2 & 900 & 2,570 & $25.4 / 600 / 598$ & 2010 \\
\hline Lünen *2 & 813 & 2,225 & $28.7 / 600 / 610$ & 2012 \\
\hline
\end{tabular}

*1 At boiler outlet (Main steam pressure, Main steam temperature, Reheat steam temperature)

*2 Tower-type boiler

*3 Commercial operation date 
IHI delivered the unit to Electric Power Development Co., Ltd. (J-POWER) with highest temperature, $620 \mathrm{deg}-\mathrm{C}$ and its reliability in operation has been confirmed as highest thermal efficiency unit of 600deg-C class USC-PC boiler. Figure.2.2 shows general arrangement of Isogo New No.2 Boiler - Owner of J-power - and Table 2.2 shows Technical data of Isogo Thermal Power Station.

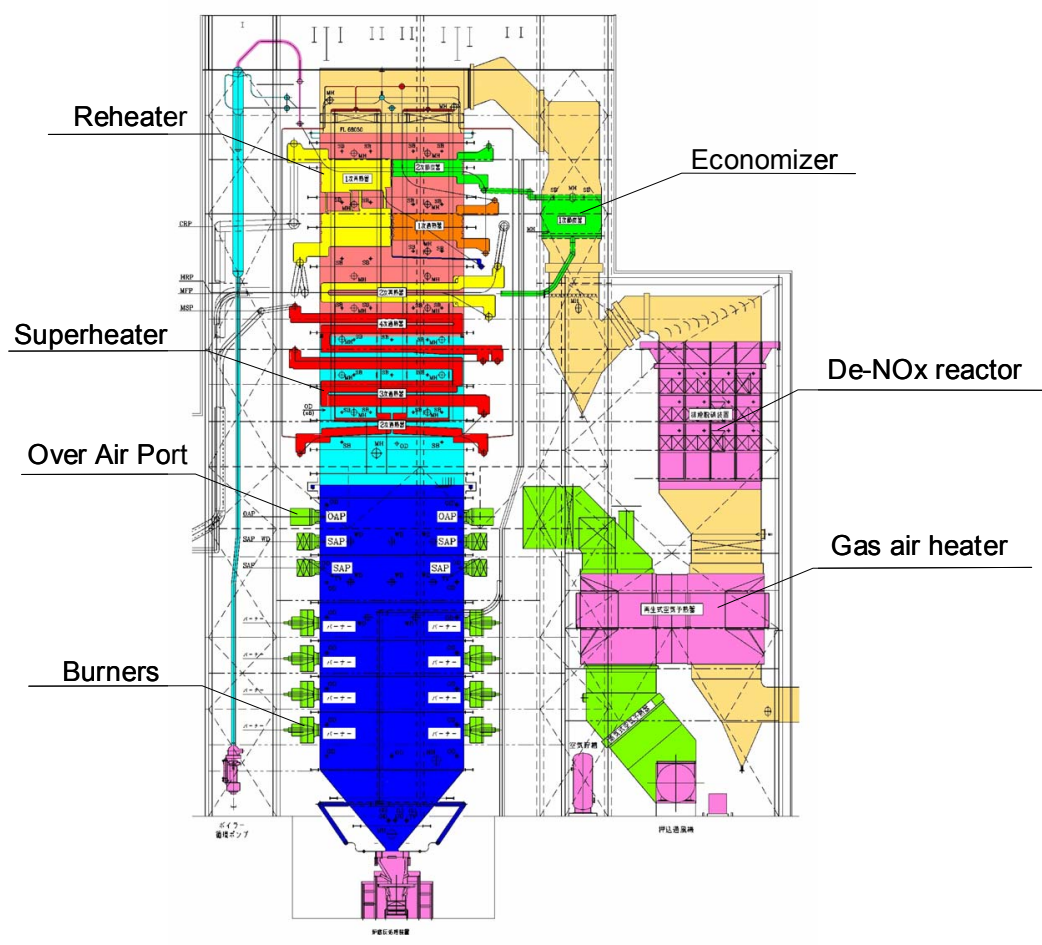

Fig. 2.2 General Arrangement of Isogo New No.2 Boiler

Table 2.2 Technical Data of Isogo Thermal Power Station

\begin{tabular}{|l|c|c|}
\hline & New No.1 unit & New No.2 unit \\
\hline \hline Unit capacity & \multicolumn{2}{|c|}{ 600MW } \\
\hline Boiler type & \multicolumn{2}{|c|}{$\begin{array}{r}\text { Supercritical Once-through Variable Pressure } \\
\text { Operation, Reheat Type }\end{array}$} \\
\hline Main steam flow & $1,710 \mathrm{t} / \mathrm{h}$ & $1,670 \mathrm{t} / \mathrm{h}$ \\
\hline Main steam pressure & $27.48 \mathrm{MPa}$ & $27.2 \mathrm{MPa}$ \\
\hline Main steam temperature & $605 \mathrm{deg}-\mathrm{C}$ & $605 \mathrm{deg}-\mathrm{C}$ \\
\hline Reheat steam temperature & $613 \mathrm{deg}-\mathrm{C}$ & $623 \mathrm{deg}-\mathrm{C}$ \\
\hline
\end{tabular}

\subsection{Development of A-USC Boilers}

In order to achieve further energy saving and global warming prevention, the development for the Advanced Ultra Super Critical pressure power generation (A-USC), that aims to commercialize 700 deg-C class PC power plant with $46-48 \%$ power generation efficiency, has been started based on the above USC-PC technology as shown in Fig.2.3. This thermal efficiency improvement is relatively more than $10 \%$ higher than the 600 deg-C class USC. That means the $\mathrm{CO}_{2}$ emission is reduced by more than $10 \%$.

Since this is confident $\mathrm{CO}_{2}$ emission reducing technology applicable to coal-fired power plant, A-USC technology development project has been started in Japan to develop 700deg-C class A-USC component technology for applying large capacity coal-fired power plant. All major boiler manufacturers and steam turbine manufacturers in Japan take part in this project as shown in Table.2.3. 
The A-USC project is consist of system design, development of material and manufacturing technology for boiler, steam turbine and valve component and test of boiler component and small turbine tests. These activities will be pursued 9-years as shown in Fig.2.4. For boiler technology, the development and evaluation of high temperature materials of large steam pipes and boiler tubes will be conducted. And the manufacturing technologies such as welding, pipe bending, etc. also will be developed.
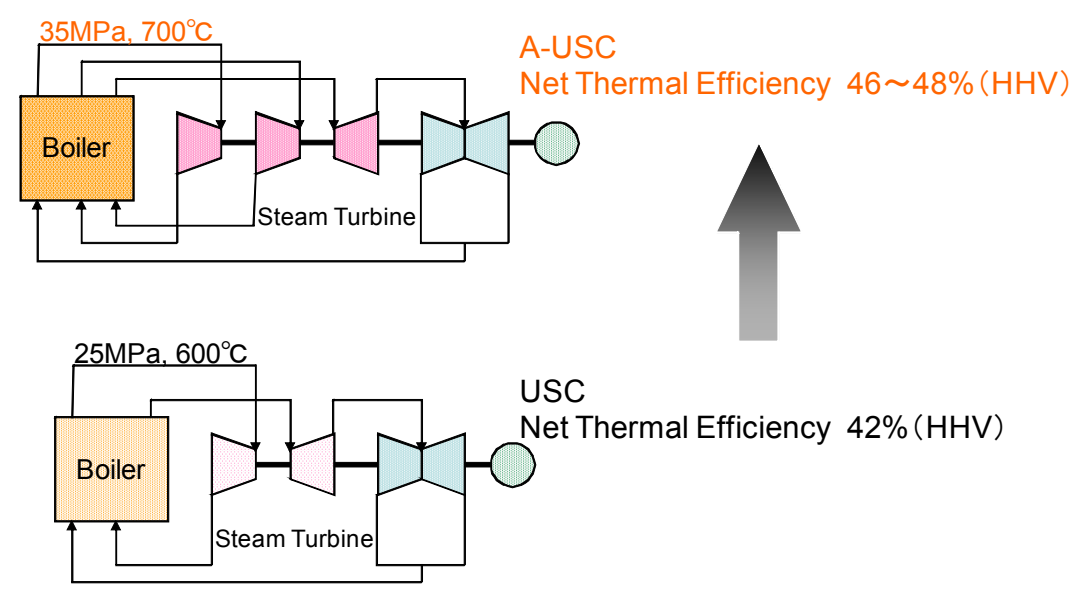

Fig. 2.3 Efficiency of A-USC Power Plant (source from ${ }^{(4)}$ )

Table 2.3 Participants of A-USC Project

\begin{tabular}{|c|c|}
\hline 1 & Babcock Hitachi K.K. \\
\hline 2 & Fuji Electric Systems Co., Ltd. \\
\hline 3 & Hitachi, Ltd. \\
\hline 4 & IHI Corporation \\
\hline 5 & Mitsubishi Heavy Industries, Ltd. \\
\hline 6 & National Institute for Materials Science(NIMS) \\
\hline 7 & Sumitomo Metal Industries, Ltd. \\
\hline 8 & Toshiba Corporation \\
\hline
\end{tabular}

\begin{tabular}{|c|c|c|c|c|c|c|c|c|c|c|}
\hline & & 2008 & 2009 & 2010 & 2011 & 2012 & 2013 & 2014 & 2015 & 2016 \\
\hline \multicolumn{2}{|c|}{ System Design } & \multicolumn{9}{|c|}{ System Design, Economics } \\
\hline \multirow{3}{*}{ Boiler Techology } & \multirow[t]{2}{*}{ Material } & \multicolumn{5}{|c|}{ Large Steam Pipe, High Temperature Tube } & & & & \\
\hline & & \multicolumn{9}{|c|}{ Long Term Test ( $>30000$ hour) } \\
\hline & Manufacturing & & Weldir & Pipe Ben & ing etc & & & & & \\
\hline \multirow{2}{*}{ Turbine Technology } & \multirow[t]{2}{*}{ Material } & \multicolumn{5}{|c|}{ Rotor, Casing, Bolt etc } & & & & \\
\hline & & \multicolumn{9}{|c|}{ Long Term Test ( $>30000$ hour) } \\
\hline \multicolumn{2}{|c|}{ Valve Technology } & \multicolumn{5}{|c|}{ Material Test, Trial Manufacturing } & & & & \\
\hline \multicolumn{2}{|c|}{ Boiler Components \& Small Turbine Test } & & & \multicolumn{3}{|c|}{ Plan, Design } & \multicolumn{2}{|c|}{ Manufacture } & \multicolumn{2}{|c|}{ 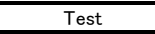 } \\
\hline
\end{tabular}

Fig. 2.4 Master Schedule of A-USC Project (source from ${ }^{(4)}$ ) 
One of big issue on development of A-USC boiler is the material development of application for high temperature components.

The temperature range for the materials of the A-USC system goes from 700 to $800 \mathrm{deg}-\mathrm{C}$, therefore, corrosion and oxidation resistance are required at 700 to $800 \mathrm{deg}-\mathrm{C}$ in combustion gas and steam environments. And it is necessary to fabricate and weld large sized components. Since considering such severe condition, the materials used for 700 deg-C class components are basically nominated $\mathrm{Ni}$ or $\mathrm{Ni}-\mathrm{Fe}$ based materials and to be newly developed and modified from conventional one as shown in Fig.2.5.

Table 2.4 shows the candidate materials for boilers. HR6W is a Ni-Fe based alloy and HR35, Alloy 617, Alloy263, Alloy740, Alloy141 are Ni based alloys for use at temperatures higher than 650deg-C. B-9Cr steel, LC-9Cr steel and SAVE 12AD are ferritic steels for use at temperatures lower than $650 \mathrm{deg}-\mathrm{C}$. These materials will be tested to verify the characteristics of creep rupture, fatigue, oxidation and corrosion. Welding and bending tests will be conducted to check the manufacturability of the materials.

\begin{tabular}{|c|c|c|c|}
\hline \multicolumn{3}{|c|}{ Conventional $\leftarrow$} & $\rightarrow$ Advanced \\
\hline Pressure (MPa) & $25 \quad 25$ & 25 & $30 \quad 30-35$ \\
\hline SH Temp*1.(deg-C) & $540 \quad 566$ & 600 & $650 \quad 700-720$ \\
\hline RH Temp ${ }^{*} \cdot(\operatorname{deg}-\mathrm{C})$ & $560 \quad 566$ & 600 & $650 \quad 700-720$ \\
\hline Water Wall & Low Cr Al & & $\begin{array}{l}\text { Mod. Low Cr } \\
\text { Alloy }\end{array}$ \\
\hline $\begin{array}{l}\text { SH, RH } \\
\text { High Temp. Part }\end{array}$ & $2.25-9 \mathrm{Cr}$ & & SUS Ni Base \\
\hline $\begin{array}{l}\text { MSP*3 } \\
\text { Header }\end{array}$ & $9-12 \mathrm{Cr}$ & & \begin{tabular}{l|l|} 
Mod. & $\begin{array}{l}\text { Ni Base } \\
\text { Austenitic } \\
\text { sus }\end{array}$ \\
$9 \mathrm{Cr}$ & \\
\end{tabular} \\
\hline $\begin{array}{l}\text { *1 SH: Superheater } \\
\text { *2 RH: Reheater } \\
\text { *3 MSP: Main steam pi }\end{array}$ & & & New Development $\mathrm{M}$ \\
\hline
\end{tabular}

Fig. 2.5 Materials of A-USC Boiler

Table 2.4 Candidate material for boilers (source from ${ }^{(4)}$ )

\begin{tabular}{|c|c|c|c|c|c|c|c|}
\hline & \multirow{2}{*}{$\begin{array}{l}\text { Creep } \\
\text { Rupture }\end{array}$} & \multirow{2}{*}{ Fatigue } & \multirow{2}{*}{ Oxidation } & \multirow{2}{*}{ Corrosion } & \multicolumn{2}{|c|}{ Bending } & \multirow{2}{*}{ Welding } \\
\hline & & & & & Pipe & Tube & \\
\hline HR6W & O & O & O & O & O & O & O \\
\hline HR35 & O & O & O & O & \multirow{2}{*}{ O } & \multirow{5}{*}{0} & O \\
\hline Alloy 617 & 0 & 0 & 0 & 0 & & & 0 \\
\hline Alloy 263 & 0 & O & O & 0 & - & & O \\
\hline Alloy 740 & O & O & O & O & - & & O \\
\hline Alloy 141 & O & O & O & O & - & & O \\
\hline B-9Cr Steel & O & O & O & O & \multirow{3}{*}{ O } & \multirow{3}{*}{ O } & O \\
\hline LC-9Cr Steel & O & O & O & O & & & O \\
\hline SAVE12AD & 0 & O & $\mathrm{O}$ & O & & & O \\
\hline
\end{tabular}




\section{Oxy-fuel Combustion Technology}

\subsection{Outline of the oxy-fuel combustion system ${ }^{(2)}$}

There are three types of $\mathrm{CO}_{2}$ capturing system from coal fired power plant as shown in Fig3.1. First, numbering (1), is oxy-fuel combustion system. Second, numbering (2), is an example of pre-combustion type applied to coal gasification system. Third, numbering (3), is an example of post-combustion type applied to a conventional boiler system. The second and third types are $\mathrm{CO}_{2}$ capturing system from fuel gas or flue gas containing $\mathrm{CO}_{2} \cdot \mathrm{CO}_{2}$ is captured with some method such as chemical absorption, physical absorption or membrane permeation. These two types are based on the similar mechanism. As compared with them oxy-fuel combustion system is based on the different mechanism.

Oxy-fuel combustion system uses $\mathrm{O}_{2}$ instead of air to burn coal. This combustion makes it possible to increase $\mathrm{CO}_{2}$ concentration in the flue gas by $90 \%$ or over theoretically, which enables to capture $\mathrm{CO}_{2}$ easily from the flue gas.

The flame temperature will be controlled by mixing the re-circulated flue gas with $\mathrm{O}_{2}$ in order to maintain the level where the conventional boiler technology can be applied. Because of no nitrogen in oxidant, the NOx emission will be relatively low compared with an air combustion system.

Although it needs additional power for oxygen production unit, this system suggests requiring less power for the $\mathrm{CO}_{2}$ separation compared with the other systems. Therefore, this system has high possibility to be more economically and efficient compared with other systems.

(1) Oxy-fuel Combustion

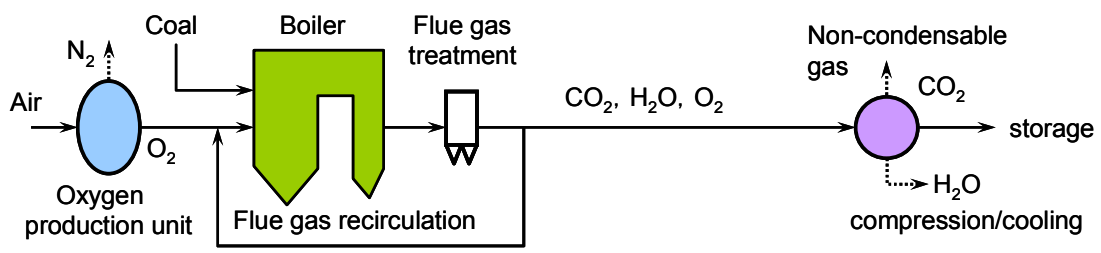

(2) Pre-combustion(Gasification)

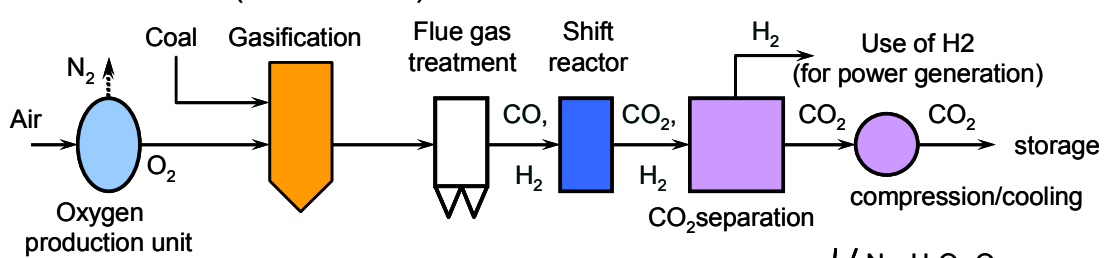

(3) Post-Combustion

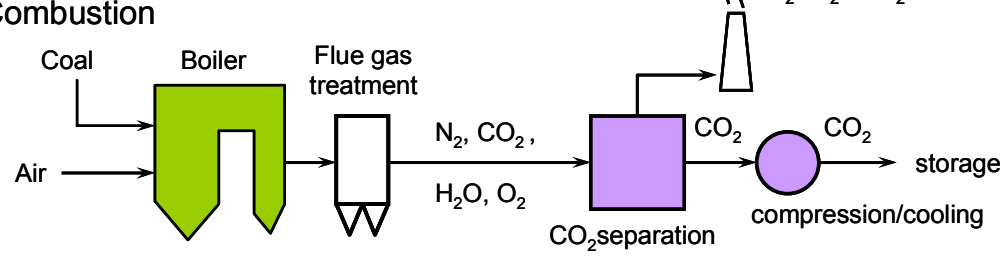

Fig. 3.1 Typical $\mathrm{CO}_{2}$ Capturing systems

\subsection{Demonstration Project in Australia}

On the basis of the previous study results ${ }^{(5)(6)}$, Joint Venture for the demonstration project of oxy-fuel combustion was established in 2008, that is called "Callide Oxy-fuel Project" (7), and the works are now under way for applying oxy-fuel combustion to an existing power plant by way of demonstration. This project aims at capturing and storage 
$\mathrm{CO}_{2}$ from an actual existing power plant and also obtaining the economical and technical data or knowledge for the commercialization. The outline of the project is as follows:

Figure.3.2 shows the site location of the existing power plant and the $\mathrm{CO}_{2}$ storage of the demonstration project. Specifically, the project is implemented at the power generation system in Callide-A power plant No.4 unit owned by CS Energy Ltd. on the east coast of Australia ${ }^{(8)}$. The capacity of this unit is $30 \mathrm{MW}$ without reheat cycle. And the main steam flow at $30 \mathrm{MW}$ is approximately $130 \mathrm{t} / \mathrm{h}$ and coal feed rate is approximately $20 \mathrm{t} / \mathrm{h}$.

Regarding the application of oxy-fuel combustion to the existing power plant, 2 of air separation units with the capacity of 330 t/day and $\mathrm{O}_{2}$ purity of $98 \%$ will be installed near the power plant, air/gas flow system of the boiler will mainly be modified and $\mathrm{CO}_{2}$ purification unit with the compression and cooling will also installed. It will be expected to have the $\mathrm{CO}_{2}$ capture rate of 50 - 100 ton per a day at the condition of the liquefied $\mathrm{CO}_{2}$. The candidate $\mathrm{CO}_{2}$ storage site is in the process of the site selection. At this stage, the area of $\mathrm{CO}_{2}$ storage is planning to be about $250 \mathrm{~km}$ to the west of the power plant site. This area was selected because it is not far away from the power plant site, the estimated $\mathrm{CO}_{2}$ storage capacity is sufficient, and the reservoir characteristics such as permeability and porosity are adequate for $\mathrm{CO}_{2}$ storage. After the decision of the site and the layer, trial drilling at storage site will be implemented.

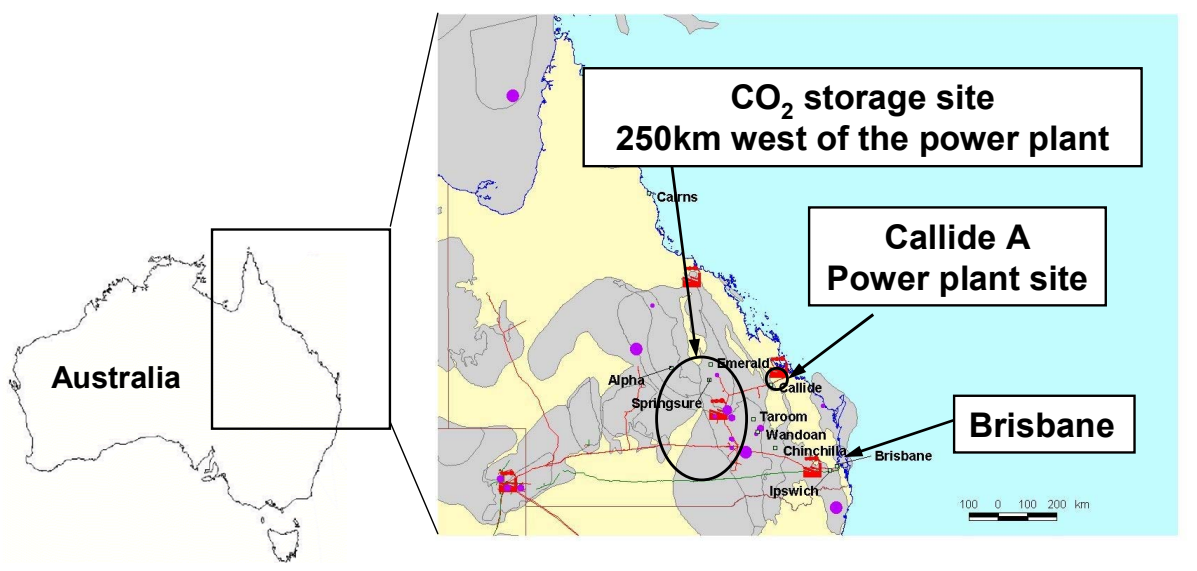

Fig. 3.2 Power Plant site and $\mathrm{CO}_{2}$ storage site

The entire schedule of the demonstration project is shown in Table 3.1. Before the moving to demonstration project, Australia and Japan jointly conducted a feasibility study of oxy-fuel combustion technology in FY $2004^{\left({ }^{9}\right)}$ and FY $2005^{(10)}$. Based on its results, detailed studies have started in 2006, aiming of the application of this technology to the existing power plant and the integration with $\mathrm{CO}_{2}$ storage. And simultaneously, the clarification of the project scheme towards the demonstration and the acquirement of the project budget were reviewed in 2006 and 2007. And, in the beginning of 2008, Joint Venture for the demonstration project was established under the supporting of both Australian and Japanese governments. Electric Power Development Co., Ltd. (J-POWER), Mitsui \& Co., Ltd. (Mitsui) and IHI Corporation (IHI) are participating in Joint Venture and Japan Coal Energy Center (JCOAL) is the supporting collaborator on technical issues from Japanese side. In November 2008, launch was held in the site to celebrate the start of site works $^{(7)}$.

Project mainly consists of stage 1 and 2. In stage 1 , demonstration operation of oxy-fuel combustion with $\mathrm{CO}_{2}$ capture will be performed after the plant completion at the middle of 2011. In stage 2, the injection of captured $\mathrm{CO}_{2}$ from the power plant will start in 2011 simultaneously, and the demonstration of $\mathrm{CO}_{2}$ injection into the underground and the monitoring of $\mathrm{CO}_{2}$ storage will be performed for three years. This demonstration project will be summarized at 2016 . 
Table 3.1 Demonstration Project Schedule

\begin{tabular}{|c|c|c|c|c|c|c|c|c|c|c|c|}
\hline Items & ,06 & , 07 & '08 & '09 & '10 & '11 & '12 & '13 & '14 & '15 & '16 \\
\hline $\begin{array}{l}\text { Stage 1 } \\
\text { Boiler retrofit \& } \\
\mathrm{CO}_{2} \text { capture }\end{array}$ & & EEED & Re & fit $x$ & rk \& \& & $\begin{array}{r}\mathrm{mmi} \\
\mathrm{Del}\end{array}$ & $\begin{array}{l}\text { sionin } \\
\text { honstre }\end{array}$ & $\begin{array}{l}\text { g } \\
\text { tion op }\end{array}$ & eration & & \\
\hline $\begin{array}{l}\underline{\text { Stage 2 }} \\
\mathrm{CO}_{2} \text { storage }\end{array}$ & & Site & electic & 1/ Tri & Co & $\begin{array}{l}\text { g } \\
\text { struct } \\
\text { CC }\end{array}$ & $\begin{array}{l}\text { on \& } \\
2_{2} \text { injec }\end{array}$ & $\begin{array}{l}\text { ommis } \\
\text { tion \& }\end{array}$ & $\begin{array}{l}\text { sioning } \\
\text { monito }\end{array}$ & & \\
\hline $\begin{array}{l}\text { Stage 3 } \\
\text { Project } \\
\text { summary }\end{array}$ & & & & & & & & & & & \\
\hline
\end{tabular}

\section{Use of Biomass Fuel}

Utilization of sustainable fuel, as biomass, is one solution for $\mathrm{CO}_{2}$ reduction in power generation. These days, high price of fossil fuel, oil especially, promotes further to install biomass and/or waste fuel firing power plants.

However, it shall be carefully considered for planning of facilities that there may be some difficulties for handling, combustion, and pulverization of biomass fuel due to their various shapes of fuel and wide range fuel properties as shown in Table 4.1 and Fig.4.1.

Table 4.1 Properties of Wooden Biomass

\begin{tabular}{|l|c|c|c|}
\hline & & Bituminous Coal & $\begin{array}{c}\text { Wooden Chip } \\
\text { with Bark }\end{array}$ \\
\hline Heating Value (HHV) & $\mathrm{MJ} / \mathrm{kg}$ & 27 & $13-16$ \\
\hline Total Moisture & $\%$ & 7.3 & $23-40$ \\
\hline Ash & $\%$ & 14.8 & 0.7 \\
\hline Volatile Matter & $\%$ & 28.4 & 83.2 \\
\hline Fixed Carbon & $\%$ & 56.8 & 16.1 \\
\hline Fuel Ratio (FC/VM) & $\%$ & 2.0 & 0.21 \\
\hline Carbon & $\%$ & 71.4 & 50.3 \\
\hline Hydrogen & $\%$ & 4.2 & 5.9 \\
\hline Nitrogen & $\%$ & 1.3 & 0.11 \\
\hline Oxygen & $\%$ & 7.9 & 43.0 \\
\hline Sulfer & $\%$ & 0.40 & 0.01 \\
\hline
\end{tabular}

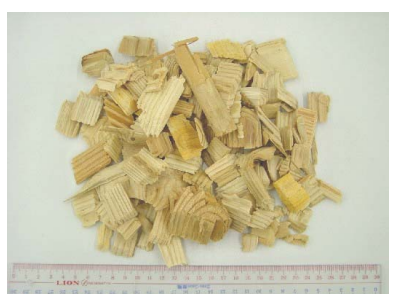

(a) Wooden Chip without bark

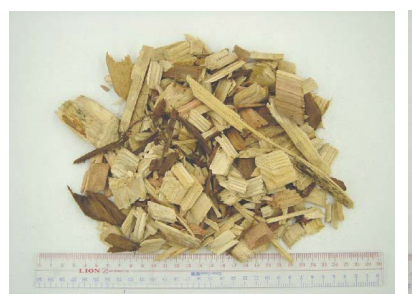

(b) Wooden Chip with bark

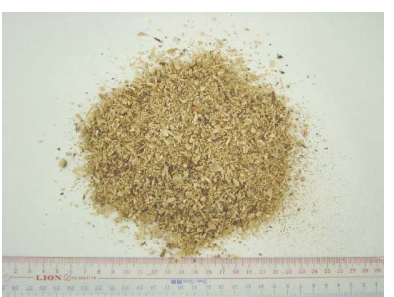

(c) Sawdust

Fig. 4.1 Various Wooden Biomass Fuel 


\subsection{Co-firing with Coal}

Recently, co-firing of wooden biomass and coal is adapted to PC boiler in Japan. The system configuration of co-firing is shown in Fig.4.2. There are two different co-firing systems. The first one is mixed pulverized system. The wooden biomass is mixed with coal at coal conveyor and storage in coal bunker. The mixed fuel is pulverized by coal pulverizer, and then fed to boiler. This system is simple and inexpensive system but capacity of wooden biomass is limited to coal pulverizer capacity. The other one is separate pulverized system. The wooden biomass is pulverized by biomass pulverizers exclusively equipped, then, fed to boiler directly. In case of adoption of this system, additional facilities are required but wooden biomass capacity can be increased with no correlation of limitation of coal pulverizer. These co-firing systems can be also applied to retrofit project of existing boiler.

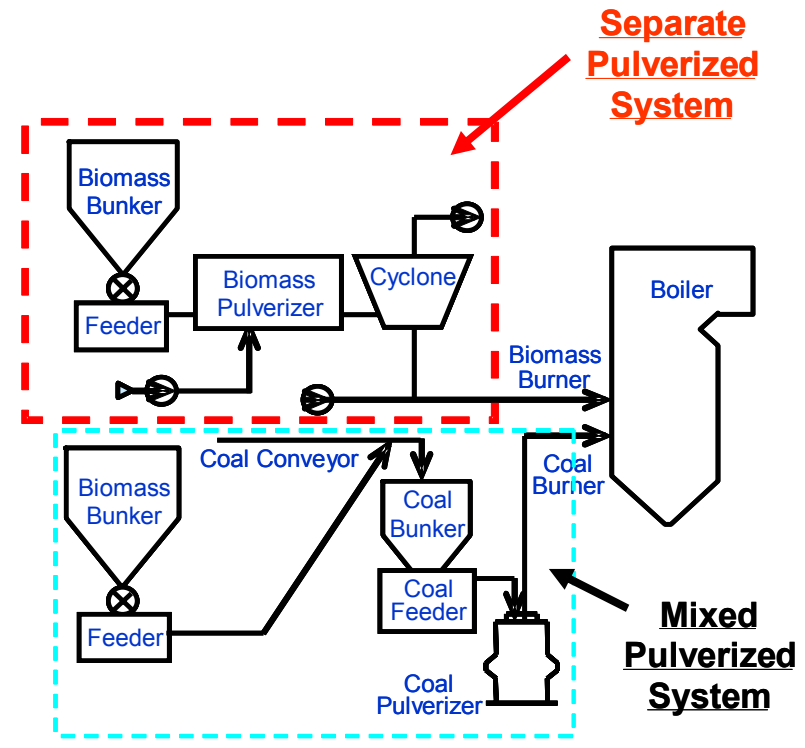

Fig. 4.2 System Configuration of Co-firing

\subsection{Application of CFB Boiler ${ }^{(1)(2)}$}

When planning biomass or waste firing boiler, it is hard to adapt PC boiler since fibrous substance as biomass cannot be pulverized practically. Therefore, Circulating Fluidized Bed (CFB) boilers have been adapted, which can handle and burn biomass efficiently without pulverization. The example of biomass and waste fuel for CFB is shown in Table 4.2.

Table 4.2 Example of Biomass and Waste Fuel

\begin{tabular}{|c|c|c|c|}
\hline Kind & RPF* & Wood Chip & Waste Tire \\
\hline Aspect & & & \\
& & & \\
Feature & $\begin{array}{c}\text { (2)Chlorine } \\
\text { (Max. 0.3wt\%) }\end{array}$ & $\begin{array}{c}\text { (1)Heating value } \\
\text { (LHV=12.6MJ/kg) }\end{array}$ & $\begin{array}{c}\text { (1)Heating value } \\
\text { (LHV=32.4MJ/kg) } \\
(2) \text { Steel wire } \\
\text { (approx.10wt\%) }\end{array}$ \\
\hline
\end{tabular}

*RPF: Refuse Paper \& Plastic Fuel (Pellet fuel of mixture of waste paper and waste plastics) 
IHI- CFB Boiler configuration is shown in Fig.4.3. In the furnace bottom, bed material such as river sand has been filled in advance and combustion air is introduced from the bottom to fluidize the bed material and blow it off to the cyclone. Almost of bed material is separated from the flue gas at the cyclone and returned to the furnace. Fuel is injected into the lower part of the furnace and mixed with combustion air thoroughly by the motion of fluidizing bed material and burned efficiently. Circulating bed material through the cyclone accomplishes higher combustion efficiency, since the un-burnt carbon in the bed material is returned to the furnace. Massive bed material having high heat capacity is preferable for combustion of waste fuel with high moisture and it is one benefit of CFB boiler.

High temperature flue gas from the cyclone enters heat recovery zone, consisting of heat exchange tubes, such as superheater and economizer. After heat recovery, the flue gas is cleaned by dust collector and desulphurization system (if any), and is discharged to the atmosphere.

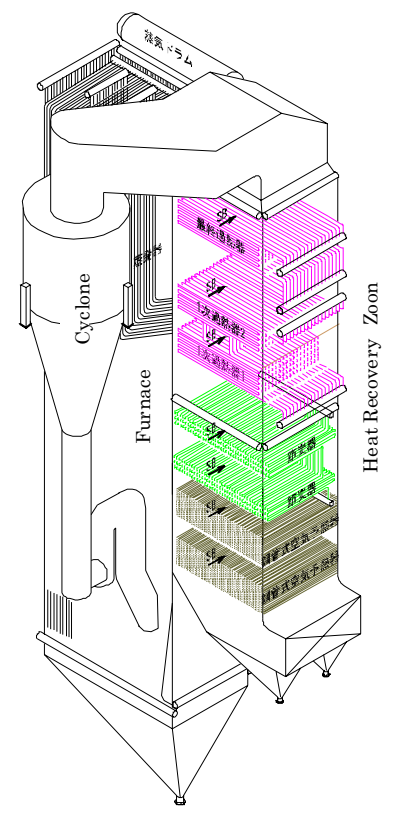

Fig. 4.3 Configuration of IHI-CFB Boiler

\section{Combination of Technology}

Three approaches to reduce $\mathrm{CO}_{2}$ emission from coal-fired power plant were aforementioned. The latest coal-fired power plant in Japan is lowest $\mathrm{CO}_{2}$ emission in the world. Furthermore, if it is possible to combine these advanced technologies, coal-fired power plants will have further potential to reduce $\mathrm{CO}_{2}$ emission in the future.

These technologies are also possible to apply replacing or retrofitting of existing power plant. This contributes to reduce $\mathrm{CO}_{2}$ emission.

\section{Conclusion}

Latest status of following advanced coal-fired boiler technologies for global warming prevention is introduced in this paper.

- Advanced Ultra Super Critical Boiler (A-USC) - Improvement in Efficiency.

- Oxy-fuel Combustion Technology - $\mathrm{CO}_{2}$ Capture

- Use of Biomass Fuel - Renewable Energy

It is obvious that these advanced technologies contribute to reduce $\mathrm{CO}_{2}$ emission economically. 


\section{References}

(1) F. Tamamushi, "Latest technology approach to reduce $\mathrm{CO}_{2}$ emission from Power Plant", Proceedings of the International Conference on Power Gen Europe 2007 (2007-6).

(2) Y. Nara, F. Tamamushi, Y. Tsumita and T. Yamada, "IHI's latest project status with $\mathrm{CO}_{2}$ emission reduction technology in thermal power plant", Proceedings of the International Conference on Power Gen Europe 2009 (2009-5).

(3) R. Mimura, "Recent Developments in Tower Type USC Boilers", Proceedings of the International Conference on Power Engineering-09 (ICOPE-09), (2009-11).

(4) M. Fukuda, E. Saito, J. Iwasaki, M. Igarashi, S. Izumi, S. Takano, S. Nakamura and T. Takahashi, "The Status of Advanced USC Technology Development in Japan", Proceedings of the International Conference on Power Engineering-09 (ICOPE-09), (2009-11).

(5) T. Yamada, T. Kiga, M.Okawa, K.Omata, N.Kimura, K.Arai, T.Mori and M.Kato "Characteristics of Pulverized-Coal Combustion in $\mathrm{CO}_{2}$-Recovery Power Plant Applied $\mathrm{O}_{2} / \mathrm{CO}_{2}$ Combustion", JSME Int. J. Ser. B, vol. 41, No. 4, 1998.

(6) H. Shimoda, M.Okawa, K.Arai, T.Yamada, T.Kiga, S.Amaike and T.Suda "Development of $\mathrm{CO}_{2}$ Recovery Type Pulverized Coal fired Power Plan Applied Oxygen and Recycled Flue Gas $\left(\mathrm{CO}_{2}\right)$ Combustion" Proc. 6th Int. Conf. on Technologies and Combustion for a Clean Environment, July, 2001, Portugal.

(7) http://www.callideoxyfuel.com

(8) C. Spero, "JAPAN-AUSTRALIA OXY-FUEL FEASIBILITY STUDY" Proc. Clean Coal Day in Japan 2004, Advanced Clean Coal Tech. Int. Symp. 2004, Sept. 2004, Tokyo.

(9) NEDO, "Report on the Clean Coal Technology Promotion Project 2004: Study on the Application of Oxygen Combustion Technology to an Existent Pulverized Coal-Fired Power Plant".

(10) NEDO, "Report on the Clean Coal Technology Promotion Project 2005: Study on the Application of Oxygen Combustion Technology to an Existent Pulverized Coal-Fired Power Plant". 